\title{
Potentialities of Pseudomonas fluorescens for Management of Fusarium Wilt Disease of Tomato in Central Himalayas
}

\author{
M.L. Joshi ${ }^{1}{ }^{*}$, Rashmi Tewari $^{2}$, Ruchi Tripathi ${ }^{2}$ and R.S. Adhikari ${ }^{1}$ \\ ${ }^{1}$ Department of Botany, GPGC, Pithoragarh, Kumaun University, \\ Nainital Uttarakhand, India \\ ${ }^{2}$ Department of Plant Pathology, College of Agriculture, G. B. Pant University of Agriculture \\ and Technology, Pantnagar-263 145, Uttarakhand, India \\ *Corresponding author
}

\section{A B S T R A C T}

\begin{tabular}{|c|}
\hline Keywords \\
\hline $\begin{array}{l}\text { Plant growth } \\
\text { promotion, Rhizo- } \\
\text { bacteria, } \\
\text { Pseudomonads, } \\
\text { Fusarium }\end{array}$ \\
\hline Article Info \\
\hline $\begin{array}{l}\text { Accepted: } \\
\text { 08 June } 2018 \\
\text { Available Online: } \\
\text { 10 July } 2018\end{array}$ \\
\hline
\end{tabular}

Keywords

Plant growth promotion, Rhizobacteria

ads

Article Info

10 July 2018
Pseudomonads are well known for their growth promotion activity and defense induction against the phytopathogens in plants leading to the disease incidence delay. Effect on the disease incidence with the interaction of different strains of Pseudomonas fluorescense were studied in tomato under protected and open conditions. The strains were isolated from different soil samples collected from various geographical regions of central Himalaya. Promising strains of Pseudomonas were applied as seed bio priming (SB), SB+ Root Dip (RD), SB+RD+ Drenching (DR) and SB+RD+DR+ Spraying (SPR) individually and in combination with different strains and evaluated for their effect on management of wilt caused by Fusarium oxysporum f. sp. lycopersici, an important disease of tomato in central Himalaya. Seeds were bio- primed with bio-formulated products RS-01, PS-01, $\mathrm{AS}-01$, and consortia of different strains RC-05, AC-05, and PC-05 before sowing. Amongst the bio- products used $\mathrm{AC}-05$ was found most effective in reducing the wilt incidence.

\section{Introduction}

Biological control can be defined as the use of natural enemies to reduce the damage by a pest population. It is an approach that fits into an overall pest management programme, and represents an alternative to continued reliance on pesticides (Cook and Baker, 1983). It has been used as a management tool for control of crop and forest pests, and for the restoration of natural systems affected by adventive pests. Biological control in the broadest sense could be defined as the use of living agents to control plant pathogens. Over the past one hundred years, research has repeatedly demonstrated that phylogenetically diverse microorganisms can act as natural antagonists of various plant pathogens (Cook, 2000). Bacterial inoculants, widely used as biocontrol agents, are applied to soil, seed or roots of agriculture crops for the suppression of soil born plant diseases. Rhizosphere bacteria with the ability to provide biological control appear to comprise less than $10 \%$ of the total population of bacteria in the rhizosphere (Weller, 1988). Specific 
rhizobacteria associated with plant roots and stimulate plant growth promoting rhizobacteria (PGPR) (Kloepper and Schroth, 1978). PGPRs induce resistance in plants and suppress plant pathogens causing fungal, bacterial and viral diseases.

Tomato (Lycopersicon esculantum Mill) is an important vegetable crop grown throughout the word moreover as a cash crop (Tewari and Vishunavat, 2012). Diseases are most limiting factors for production of tomato leading to a reduction in its quantity and market value. The major fungal diseases of tomato are early blight, late blight, damping off, root rot, buckey rot (fruit rot), fusarium wilt, collar rot, powdery mildew, white rot, gray leaf spot, verticillium wilt, anthracnose and black leaf mould. Wilt caused by Fusarium oxysporum pv. lycopersici is an important disease in central Himalaya, which may have devastating effects on economy of farming community, if the disease is of epidemic nature and not under control (Whipps and Lumsden, 1991). The causal organism is of soil - borne in nature and difficult to control, thus making the development of alternatives a high priority (Lemanceau et al., 1992). Pseudomonads spp. are well known to show positive interaction with microorganisms resulting in growth promotion in plants and simultaneously activating the disease incidence delay by synthesizing antibodies and growth promoting substance. Keeping in view the efficacy of Pseudomonads spp as PGPR and as an antagonist, the present study was conducted to investigate these for prospective management of Fusarium wilt disease of tomato in Central Himalayan regions.

\section{Materials and Methods}

Isolation and identification of Pseudomonads

Different soil samples having $\mathrm{pH}$ values ranging from 5.75 to 6.77 were collected from diverse agro climatic locations of central Himalayan regions of Uttarakhand viz., Auli (9000'), Pithoragarh (5500') and Raiwala (942'). Susceptible cultivars of tomato were grown in pots filled with these soil samples. The plants were gently uprooted with approximately $10 \mathrm{~cm}$ diameter core of surrounding soil with least possible injury to the roots. Root system and surrounding soil were placed in plastic bags and transported back to the laboratory in an ice chest. After vigorous shaking of excited roots to remove tightly adhering soil, $1 \mathrm{~g}$ of soil was mixed with $9 \mathrm{ml}$ sterilized distilled water under aseptic conditions to make the dilution 10-1. This was further diluted up to 10-7 dilutions. The rhizospheric suspensions were plated (1ml) on Kings' B medium (KB) (King et al; $1954)$ by streaking method. After $48 \mathrm{~h}$. of growth at $28 \pm 1^{\circ} \mathrm{C}$, dominant fluorescent colonies were viewed under UV light and selected on the basis of colony characters and morphology of the bacteria and subjected to single colony isolation. The bacterial strains then selected were sent to Institute of Microbial Technology (I M Tech) Chandigarh for identification as well as transferred on the Kings' B slants and kept at $4^{\circ} \mathrm{C}$ for further studies. Pure culture of test pathogen Fusarium oxysporum was initially collected from IARI Delhi.

Talc based formulation of effective strains of Pseudomonas were prepared by mixing autoclaved Carboxy methyl cellulose (CMC) and talc powder@1\% w/w with bacterial strains grown on $\mathrm{KB}$ broth for 48 hours in incubator shaker at $150 \mathrm{rpm}$ and $27 \pm 1^{\circ} \mathrm{C}$ for 24 hours on each of two consecutive days. $500 \mathrm{ml}$ of the bacterial suspension containing 2X109 colony forming units (cfu) per ml was added to one $\mathrm{kg}$ of the carrier, mixed thoroughly and left overnight for complete drying. For the preparation of mixed formulation $100 \mathrm{ml}$ broth of each bacterial suspension was mixed in one $\mathrm{kg}$ carrier. 
Screening of Fluorescent Pseudomonas against $F$. oxysporum through in vitro antagonism

The antagonistic activity of different strains of Pseudomonas against the pathogenic fungi was assessed on agar plates as described by Weller et al., (1988) with slight modifications. A combination of two media (KB+PDA 1:1) was used for this purpose. Pure culture of bacterial strains was grown on Kings' B broth and fungal pathogen maintained on PDA slants was transferred to Petri dishes containing fresh PDA to produce fungal mycelium plugs. Petriplates were inoculated with the help of sterilized glass bangle and a 5 $\mathrm{mm}$ mycelial disc (from actively growing colony of the test pathogen) was cut with the help of sterilized cork borer and placed in the centre of Petri dish. These inoculated plates were incubated at $28 \pm 1^{\circ} \mathrm{C}$. Maximum and minimum inhibition zones were measured after 48, 72, 96 hours. The plates without bacteria served as control. Three replications were taken for each treatment.

\section{Assessment of disease suppression potential of Pseudomonads}

Seeds of tomato var. Punjab Chhuhara were surface sterilized with 2 per cent sodium hypochloride for 30 seconds and rinsed in sterilized distilled water and dried overnight. Sterilized seeds were treated with 10 per cent solution of bio formulations for 30 minutes and then dried in sterile airflow overnight. Treated seeds were planted into the pots $(60 \mathrm{X} 45 \mathrm{cmX} 10 \mathrm{~cm}$ Size), and field under glass house conditions. Three replications were made for each treatment and observations with respect to disease incidence were recorded. To record the performance of various treatments, during crop growth stage, transplanting was done in pots as well as in field under glass house. Bio formulation treatments were given as (a) Seed bio-priming + root dip $(\mathrm{SB}+\mathrm{RD})$ (b) $\mathrm{SB}+\mathrm{RD}+\mathrm{Dreanching}(\mathrm{SB}+\mathrm{RD}+\mathrm{DR})$ (c) $\mathrm{SB}+\mathrm{RD}+\mathrm{DR}+$ foliar spray $(\mathrm{SB}+\mathrm{RD}+\mathrm{DR}+\mathrm{SPR})$. Drenching and root dip @ 10 per cent whereas foliar spray @ 5 per cent bio formulation was done. Experiments were set in triplicate, in randomized arrangement. Observations with respect to disease incidence at seedling and crop stage were recorded for two crop seasons.

\section{Results and Discussion}

\section{Isolation and identification Fluorescent pseudomonads}

Eighty six strains of Pseudomonads were collected from different regions of central Himalayas. The isolated cultures were send for identification to Institute of Microbial Technology (IMTech) Chandigarh, and were identified as different strains of Fluorescent pseudomonas, on the basis of morphological and chemical characters. Pure cultures of pathogenic fungi, Fusarium oxisporum causing wilt disease of tomato in central Himalayan region was brought from IARI Delhi. These cultures were used for antagonistic activity assessment as well as for inoculation of tomato plants. The plants inoculated with the cultures showed wilting symptoms.

\section{Symptomatology}

Fusarium oxysporum and its various forms have been characterized as causing the following symptoms viz. vascular wilt, yellows, corm rot, root rot, and damping-off. Fusarium wilts first appear as slight vein clearing on the outer portion of the younger leaves, followed by epinasty (downward drooping) of the older leaves. At seedling stage, plants showed wilting and death soon after symptoms appearance. In older plants, vein clearing and leaf epinasty often followed by stunting, yellowing of the lower leaves, 
formation of adventitious roots, wilting of leaves and young stems, defoliation, marginal necrosis of remaining leaves, and finally death of the entire plant was observed.

Browning of the vascular tissue is strong evidence of Fusarium wilt. Further, on older plants, symptoms generally become more apparent during the period between blossoming and fruit maturation (Altinok, 2005).

\section{In vitro screening of Fluorescent Pseudomonads against F. oxysporum}

Pseudomonads when screened against Fusarium oxisporum, the strains isolated from the soil samples collected from Auli (AULI200, AULI-178, AULI-185, AULI-188, AULI-187) were most antagonistic followed by those from the soil samples of Pithoragarh (P GGu-667, P JB-669, P JB-531, P GI-446, P JB-662) and Raiwala (R RWL-128, R RWL308, R GRW-329, R GRW-118, R RWL-330) where maximum zone of inhibition was recorded. The Auli strains isolated from the higher hills were comparatively more effective than that of lower hills.

\section{In vivo screening through seed bio-priming}

The effect of formulated products on disease incidence was studied in tomato variety Punjab Chhuhara. Seeds were bio- primed with bio-formulated products RS-01 (strain R RWL-128), PS-01 (strain P GGu-667), AS-01 (strain AULI-185) and consortia of different strains RC-05 (consortia of R RWL-128, R RWL-308, R GRW-329, R GRW-118, R RWL-330), AC-05 (consortia of AULI-200, AULI-178, AULI-185, AULI-188, AULI187), and PC-05 (consortia of P GGu-667, $P$ JB-669, P JB-531, P GI-446, P JB-662) before sowing. Formulated products which were prepared by mixing five effective strains showed higher efficacy towards disease suppression as compared to those prepared using single bacterial strain. Amongst the bioproducts used AC-05 was found most effective in reducing the wilt incidence as minimum wilting 3.7 per cent, 5.3 per cent, 10.7 per cent and 11.3 per cent wilting was recorded after 10, 15, 20 and 25 days after germination respectively in pot conditions. Bio-inoculant AC-05 was also found highly significant in reducing the wilting under field conditions (Table 1).

Table.1 Progressive disease incidence at seedling stage in pots and field under protected conditions

\begin{tabular}{|l|c|c|c|c|c|c|c|c|}
\hline \multirow{2}{*}{ Treatment } & \multicolumn{7}{|c|}{ Disease incidence (\%) } \\
\cline { 2 - 8 } & \multicolumn{3}{|c|}{ Pot conditions } & \multicolumn{4}{c|}{ Field conditions } \\
\cline { 2 - 9 } & 10 & 15 & 20 & 25 & 10 & 15 & 20 & $\mathbf{2 5}$ \\
\hline RS-01 & 16.3 & 18.3 & 24.7 & 25.3 & 16.0 & 20.0 & 29.0 & $\mathbf{3 0 . 0}$ \\
\hline PS-01 & 11.7 & 14.7 & 20.3 & 22.3 & 15.0 & 18.0 & 26.0 & $\mathbf{2 8 . 0}$ \\
\hline AS-01 & 5.3 & 8.3 & 12.6 & 15.3 & 08.0 & 10.0 & 18.0 & $\mathbf{1 9 . 0}$ \\
\hline RC-05 & 10.3 & 12.3 & 14.3 & 17.3 & 12.0 & 15.0 & 22.0 & $\mathbf{2 4 . 0}$ \\
\hline AC-05 & 3.7 & 5.3 & 10.7 & 11.3 & 5.0 & 07.0 & 12.0 & $\mathbf{1 3 . 0}$ \\
\hline PC-05 & 5.3 & 6.3 & 11.3 & 12.3 & 6.0 & 08.0 & 14.0 & $\mathbf{1 6 . 0}$ \\
\hline Control & 25.0 & 27.3 & 36.6 & 40.0 & 30.0 & 34.0 & 48.0 & $\mathbf{5 3 . 0}$ \\
\hline CD at 5 \% & 20.376 & 17.130 & 10.390 & 8.212 & 20.104 & 14.173 & 08.234 & $\mathbf{0 8 . 8 3 3}$ \\
\hline CV & $\mathbf{1 . 3 0 5}$ & $\mathbf{1 . 3 0 9}$ & $\mathbf{1 . 1 1 9}$ & $\mathbf{0 . 9 7 9}$ & $\mathbf{1 . 5 7 8}$ & $\mathbf{1 . 3 0 9}$ & $\mathbf{1 . 1 4 7}$ & $\mathbf{1 . 3 3 3}$ \\
\hline
\end{tabular}


Table.2 Progressive disease incidence at different crop stages in pots under protected conditions

\begin{tabular}{|c|c|c|c|c|c|c|c|c|c|c|c|c|c|c|c|}
\hline \multirow[t]{3}{*}{ Treatments } & \multicolumn{15}{|c|}{ Disease incidence (\%) } \\
\hline & \multicolumn{3}{|c|}{$15 \mathrm{DAT}$} & \multicolumn{3}{|c|}{$30 \mathrm{DAT}$} & \multicolumn{3}{|c|}{$45 \mathrm{DAT}$} & \multicolumn{3}{|c|}{$60 \mathrm{DAT}$} & \multicolumn{3}{|c|}{90 DAT } \\
\hline & $\mathrm{SB}+\mathrm{RD}$ & $\begin{array}{l}\mathrm{SB}+\mathrm{RD} \\
+\mathrm{DR}\end{array}$ & $\begin{array}{l}\mathrm{SB}+\mathrm{RD}+ \\
\mathrm{DR}+\mathrm{SPR}\end{array}$ & $\mathrm{SB}+\mathrm{RD}$ & $\begin{array}{l}\mathrm{SB}+\mathrm{RD} \\
+\mathrm{DR}\end{array}$ & $\begin{array}{l}\mathrm{SB}+\mathrm{RD}+ \\
\mathrm{DR}+\mathrm{SPR}\end{array}$ & $\mathrm{SB}+\mathrm{RD}$ & $\begin{array}{l}\mathrm{SB}+\mathrm{RD} \\
+\mathrm{DR}\end{array}$ & $\begin{array}{l}\mathrm{SB}+\mathrm{RD}+ \\
\mathrm{DR}+\mathrm{SPR}\end{array}$ & $\mathrm{SB}+\mathrm{RD}$ & $\begin{array}{l}\mathrm{SB}+\mathrm{RD} \\
+\mathrm{DR}\end{array}$ & $\begin{array}{l}\mathrm{SB}+\mathrm{RD}+ \\
\mathrm{DR}+\mathrm{SPR}\end{array}$ & $\mathrm{SB}+\mathrm{RD}$ & $\begin{array}{l}\mathrm{SB}+\mathrm{RD} \\
+\mathrm{DR}\end{array}$ & $\begin{array}{l}\text { SB+RD+ } \\
\text { DR+SPF }\end{array}$ \\
\hline AC-05 & 9.14 & 5.29 & 7.84 & 11.06 & 9.66 & 12.00 & 35.58 & 30.73 & 24.27 & 48.89 & 37.15 & 30.25 & 59.10 & 44.52 & 41.41 \\
\hline RC-05 & 15.77 & 12.27 & 12.81 & 28.22 & 25.24 & 25.04 & 53.24 & 39.10 & 26.90 & 71.42 & 50.32 & 43.67 & 89.25 & 68.45 & 59.17 \\
\hline PC-05 & 10.42 & 8.61 & 9.37 & 19.20 & 17.37 & 21.38 & 50.19 & 39.88 & 27.70 & 68.03 & 47.33 & 43.21 & 83.68 & 77.09 & 52.53 \\
\hline Control & \multicolumn{3}{|l|}{18.53} & \multicolumn{3}{|l|}{34.42} & \multicolumn{3}{|l|}{62.81} & \multicolumn{3}{|l|}{77.53} & \multicolumn{3}{|l|}{93.85} \\
\hline CD at $5 \%$ & \multicolumn{3}{|c|}{$\begin{array}{l}(a)=.838(b)=.967 \\
\left(a^{*} b\right)=1.676\end{array}$} & \multicolumn{3}{|c|}{$\begin{array}{l}(a)=1.286 \quad(b)=1.485 \\
(a * b)=2.573\end{array}$} & \multicolumn{3}{|c|}{$\begin{array}{l}(a)=2.118(b)=2.446 \\
(a * b)=4.237\end{array}$} & \multicolumn{3}{|c|}{$\begin{array}{l}(a)=4094 \\
(b)=4.727\left(a^{*} b\right)=8.188\end{array}$} & \multicolumn{3}{|c|}{$\begin{array}{l}(a)=1.642(b)=1.896 \\
\left(a^{*} b\right)=3.285\end{array}$} \\
\hline CV & \multicolumn{3}{|l|}{8.072} & \multicolumn{3}{|l|}{6.693} & \multicolumn{3}{|l|}{5.819} & \multicolumn{3}{|l|}{8.753} & \multicolumn{3}{|l|}{2.717} \\
\hline
\end{tabular}

Table.3 Progressive disease incidence at different crop stages in fields under protected conditions

\begin{tabular}{|c|c|c|c|c|c|c|c|c|c|c|c|c|c|c|c|}
\hline \multirow{4}{*}{$\begin{array}{l}\text { Treatments } \\
\text { AC-05 }\end{array}$} & \multicolumn{15}{|c|}{ Disease incidence (\%) } \\
\hline & \multicolumn{3}{|c|}{$15 \mathrm{DAT}$} & \multicolumn{3}{|c|}{$30 \mathrm{DAT}$} & \multicolumn{3}{|c|}{$45 \mathrm{DAT}$} & \multicolumn{3}{|c|}{60 DAT } & \multicolumn{3}{|c|}{90 DAT } \\
\hline & $\mathrm{SB}+\mathrm{RD}$ & $\begin{array}{l}\mathrm{SB}+\mathrm{RD} \\
+\mathrm{DR}\end{array}$ & $\begin{array}{l}\mathrm{SB}+\mathrm{RD}+ \\
\mathrm{DR}+\mathrm{SPR}\end{array}$ & $\mathrm{SB}+\mathrm{RD}$ & $\begin{array}{l}\mathrm{SB}+\mathrm{RD} \\
+\mathrm{DR}\end{array}$ & $\begin{array}{l}\mathrm{SB}+\mathrm{RD}+ \\
\mathrm{DR}+\mathrm{SPR}\end{array}$ & $\mathrm{SB}+\mathrm{RD}$ & $\begin{array}{l}\mathrm{SB}+\mathrm{RD} \\
+\mathrm{DR}\end{array}$ & $\begin{array}{l}\mathrm{SB}+\mathrm{RD}-1 \\
\mathrm{DR}+\mathrm{SPF}\end{array}$ & $\mathrm{SB}+\mathrm{RD}$ & $\begin{array}{l}\mathrm{SB}+\mathrm{RD} \\
+\mathrm{DR}\end{array}$ & $\begin{array}{l}\text { SB+RD- } \\
\text { DR+SPF }\end{array}$ & $\mathrm{SB}+\mathrm{RD}$ & $\begin{array}{l}\mathrm{SB}+\mathrm{RD} \\
+\mathrm{DR}\end{array}$ & $\begin{array}{l}\mathrm{SB}+\mathrm{RD}+ \\
\mathrm{DR}+\mathrm{SPR}\end{array}$ \\
\hline & 7.81 & 2.76 & 5.81 & 9.64 & 10.57 & 6.73 & 31.69 & 24.63 & 17.73 & 42.62 & 33.62 & 27.59 & 58.18 & 43.67 & 39.67 \\
\hline RC-05 & 9.38 & 9.84 & 9.90 & 22.33 & 20.49 & 21.53 & 50.52 & 37.57 & 22.12 & 64.50 & 42.49 & 40.07 & 83.07 & 66.59 & 57.41 \\
\hline PC-05 & 9.76 & 7.15 & 7.34 & 15.70 & 18.72 & 14.16 & 42.26 & 32.37 & 21.52 & 54.96 & 48.31 & 35.07 & 77.42 & 73.47 & 49.36 \\
\hline Control & \multicolumn{3}{|l|}{18.34} & \multicolumn{3}{|l|}{29.75} & \multicolumn{3}{|l|}{59.00} & \multicolumn{3}{|l|}{72.81} & \multicolumn{3}{|l|}{88.32} \\
\hline CD at $5 \%$ & \multicolumn{3}{|c|}{$\begin{array}{l}(a)=1.127 \\
(a * b)=2.255\end{array}$} & \multicolumn{3}{|c|}{$\begin{array}{l}(a)=0.943 \\
(a * b)=1.886\end{array}$} & \multicolumn{3}{|c|}{$\begin{array}{l}(a)=1.085 \quad(b)=1.253 \\
\left(a^{*} b\right)=2.170\end{array}$} & \multicolumn{3}{|c|}{$\begin{array}{ll}(a)=1.326 & (b)=1.531 \\
\left(a^{*} b\right)=2.653\end{array}$} & \multicolumn{3}{|c|}{$\begin{array}{l}(a)=1.171(b)=1.352 \\
(a * b)=2.342\end{array}$} \\
\hline $\mathbf{C V}$ & \multicolumn{3}{|l|}{12.803} & \multicolumn{3}{|l|}{05.832} & \multicolumn{3}{|c|}{03.362} & \multicolumn{3}{|c|}{03.094} & \multicolumn{3}{|c|}{02.039} \\
\hline
\end{tabular}


Table.4 Progressive disease incidence at different crop stages in open field conditions

\begin{tabular}{|c|c|c|c|c|c|c|c|c|c|c|c|c|c|c|c|}
\hline \multirow[t]{3}{*}{ Treatments } & \multicolumn{15}{|c|}{ Disease incidence $(\%)$} \\
\hline & \multicolumn{3}{|c|}{15 DAYS } & \multicolumn{3}{|c|}{30 DAYS } & \multicolumn{3}{|c|}{45 DAYS } & \multicolumn{3}{|c|}{60 DAYS } & \multicolumn{3}{|c|}{90 DAYS } \\
\hline & $\mathrm{SB}+\mathrm{RD}$ & $\begin{array}{l}\mathrm{SB}+\mathrm{RD} \\
+\mathrm{DR}\end{array}$ & $\begin{array}{l}\mathrm{SB}+\mathrm{RD}+ \\
\mathrm{DR}+\mathrm{SPR}\end{array}$ & $\mathrm{SB}+\mathrm{RD}$ & $\begin{array}{l}\mathrm{SB}+\mathrm{RD} \\
+\mathrm{DR}\end{array}$ & $\begin{array}{l}\mathrm{SB}+\mathrm{RD}+ \\
\mathrm{DR}+\mathrm{SPR}\end{array}$ & $\mathrm{SB}+\mathrm{RD}$ & $\begin{array}{l}\mathrm{SB}+\mathrm{RD} \\
+\mathrm{DR}\end{array}$ & $\begin{array}{l}\mathrm{SB}+\mathrm{RD}+ \\
\mathrm{DR}+\mathrm{SPR}\end{array}$ & $\mathrm{SB}+\mathrm{RD}$ & $\begin{array}{l}\mathrm{SB}+\mathrm{RD} \\
+\mathrm{DR}\end{array}$ & $\begin{array}{l}\mathrm{SB}+\mathrm{RD}+ \\
\mathrm{DR}+\mathrm{SPR}\end{array}$ & $\mathrm{SB}+\mathrm{RD}$ & $\begin{array}{l}\mathrm{SB}+\mathrm{RD} \\
+\mathrm{DR}\end{array}$ & $\begin{array}{l}\text { SB+RD+ } \\
\text { DR+SPR }\end{array}$ \\
\hline $\mathrm{AC}-05$ & 7.05 & 2.31 & 5.41 & 6.82 & 9.02 & 5.19 & 30.02 & 22.08 & 14.57 & 40.10 & 30.31 & 25.68 & 56.14 & 40.71 & 38.69 \\
\hline RC-05 & 11.14 & 9.11 & 9.78 & 18.99 & 20.07 & 18.41 & 48.43 & 36.55 & 20.49 & 62.75 & 41.60 & 39.75 & 72.23 & 62.00 & 56.63 \\
\hline PC-05 & 8.48 & 5.44 & 7.05 & 14.00 & 16.05 & 12.00 & 40.13 & 30.89 & 18.13 & 51.90 & 45.84 & 30.83 & 70.73 & 69.78 & 42.83 \\
\hline Control & \multicolumn{3}{|l|}{14.05} & \multicolumn{3}{|l|}{24.96} & \multicolumn{3}{|l|}{56.68} & \multicolumn{3}{|l|}{70.77} & \multicolumn{3}{|l|}{80.93} \\
\hline CD at $5 \%$ & \multicolumn{3}{|c|}{$(a)=.491(b)=.567(a * b)=.982$} & \multicolumn{3}{|c|}{$\begin{array}{l}(a)=.263 \\
(a * b)=.527\end{array}$} & \multicolumn{3}{|c|}{$\begin{array}{l}(a)=.331 \\
(a * b)=.662\end{array}$} & \multicolumn{3}{|c|}{$\begin{array}{l}(a)=.375 \\
(a * b)=.750\end{array}$} & \multicolumn{2}{|c|}{$\begin{array}{l}(\mathbf{a})=.351 \\
(\mathbf{a} * \mathbf{b})=.702\end{array}$} & $(b)=.405$ \\
\hline CV & \multicolumn{3}{|l|}{6.452} & \multicolumn{3}{|l|}{1.913} & \multicolumn{3}{|l|}{1.088} & \multicolumn{3}{|l|}{0.915} & \multicolumn{3}{|l|}{0.661} \\
\hline
\end{tabular}


All other formulations when bio-primed in seeds showed significantly effective outcome in reducing the wilting of seedlings as compare to control. Suppression of plant pathogenic fungi and production of antifungal compounds by Pseudomonas spp. is also documented (Anitha and Tripathi, 2001; Bhowmik et al., 2002; Gupta et al., 2001). Pseudomonas fluorescens could act as strong elicitors of plant defense reactions (Piga et al., 1997).

\section{Effect of fluorescent Pseudomonads on disease suppression at different crop stages}

Bio-formulated products RC-05, AC-05 and PC-05 prepared as consortia of different strains which were found effective at seedling stage were further assessed for their affectivity towards disease suppression at different crop stages after transplanting. Different sets of application methods as seed bio-priming (SB), root dip (RD), drenching (DR) and foliar spray (SPR) were followed and all the treatments in either of the application method were found effective as compared to control in both protected and open field conditions.

Under protected conditions, when seedlings were transplanted in pots as well as in field, minimum disease incidence was observed in AC-05 than other formulations in different crop stages up to 90 days of transplanting (DAT). However, all the formulations were found significantly effective than control in reducing the disease incidence (Table 2 and 3).

Among the methods of application, $\mathrm{SB}+\mathrm{RD}+\mathrm{DR}+\mathrm{SPR}$ was found superior as disease incidence was observed least followed by $\mathrm{SB}+\mathrm{RD}+\mathrm{DR}$ and $\mathrm{SB}+\mathrm{RD}$. All the formulations were found significantly effective in managing the disease in different methods of applications. Similar trend of observations were also recorded in the open field conditions (Table 4). AC-05 product showed minimum wilting in different crop stages. However, during initial 30 DAT there was less difference among the bio-products treatments for disease management but after 90 days of transplanting significant difference was observed. The studies show that the wilt incidence has been delayed with different sets of treatments in different crop stages. It confirms that prior application of bioinoculants in various combinations and different sets of applications, induces the plant's own defense mechanism which enhanced the production of defense related chemicals and enzymes in pants (Chenand Belanger et al., 2000 and Masya et al., 2010).

\section{References}

Altinok HH. (2005). First report of fusarium wilt of eggplant caused by Fusarium oxysporum f. sp. melongenae in Turkey. Plant Pathology.54, 577.

Anitha K, Tripathi NN. 2001. Laboratory screening of fungal and bacterial antagonists against Rhizoctonia solani khun. and Pythium aphanidermatum (Edson) Fitz. inciting seedling diseases of okra. Indian Journal of Plant Protection 29: 46-148.

Bhowmik B, Singh, RP, Jayaraman J, Verma JP. 2002. Population dynamics of cotton endophytic Pseudomonas their antagonism and protective action against the major pathogens of cotton. Indian Phytopathology 55:124-132.

Chin C, Belanger RR., Benhamou N, Pauliz TC. 2000. Defense enzymes induced in cucumber roots by treatment with plant growth promoting rhizobacteria (PGPR) and Pythium aphanidermatum. Physiological and Molecular Plant Pathology 56:13-23

Cook RJ, Baker KF. 1983. The nature and practices of biological control of plant 
pathogens. APS Books, St. Paul. MN, U.S.A., 599 pp.

Cook RJ. 2002. Advances in plant health management in the twentieth century. Annual Review of Phytopathology 38:95-116

Gupta CP, Dubey RC, Kang SC, Maheshwari DK. 2001. Antibiosis mediated necrotrophic effect of Pseudomonas GRC2 against two fungal plant pathogens. Current Science 81: 91-94.

King EO, Ward MK, Raney DE. 1954. Two simple media for demonstration of pyocyanin and fluorescein. Journal of Laboratory and Clinical Medicine 44:301-307

Kloepper JW, Schroth MN. 1978. Plant growth promoting rhizobacteria on radishes. In Station de Pathogie Vegetable et Jphytobacteriologie (ed.), Proceedings of the 4th international conference on plant pathogenic bacteria, I.N.R.A., Ronte de Saint Cleament Beaucauze, Angers. Gillbert-Clarey, Tonrs, Volume 11, pp.879-82.

Lemanceau P, Bakker AHMP, Kogel WJD, Alabouvette C, Schippers B. 1992. Effect of psedobactin 358 production by Pseudomonas putida on suppression of Fusarium wilt of carnations by nonpathogenic Fusarium oxysporum Fo47. Applied and environmental microbiology. 58(9):2978-2982.

M' Piga P, RR Belanger, T. Paulitz, N Benhamou. 1997. Increased resistance to Fusarium oxysporum $f$. sp. radicis lycopersici in tomato plants treated with the endophytic bacterium pseudomonas fluorescens strain 63-28. Physiological and Molecular Plant Pathology 50: 301-320.

Masya E, Fishal M, Meon S, Mui, WY. 2010. Induction of Tolerance to Fusarium Wilt and Defense-Related Mechanisms in the Plantlets of Susceptible Berangan Banana PreInoculated with Pseudomonas sp. (UPMP3) and Burkholderia sp. (UPMB3). Agricultural Sciences in China 9(8): 1140-1149

Tewari, R. and Vishunavat, K. 2012. Management of early blight (Alternaria solani) in tomato by integration of fungicides and cultural practices. International Journal of Plant Protection 5 (2):201-206.

Weller DM. 1988. Biological control of soil born plant pathogens in the rhizosphere with bacteria. Annual Review of Phytopathology 26: 379407.

Whipps JM, Lumsden DR. 1991. Biological control Pythium species. Biocontrol Science and Technology 1:75-90.

\section{How to cite this article:}

Joshi, M.L., Rashmi Tewari, Ruchi Tripathi and Adhikari, R.S. 2018. Potentialities of Pseudomonas fluorescens for Management of Fusarium Wilt Disease of Tomato in Central Himalayas. Int.J.Curr.Microbiol.App.Sci. 7(07): 1167-1174. doi: https://doi.org/10.20546/ijcmas.2018.707.141 